\title{
Erratum to: The DNA methyltransferase inhibitor zebularine exerts antitumor effects and reveals $B A T F 2$ as a poor prognostic marker for childhood medulloblastoma
}

\author{
Augusto Faria Andrade ${ }^{1,2}$ - Kleiton Silva Borges ${ }^{3}$ - Veridiana Kiill Suazo ${ }^{3}$. \\ Lenisa Geron ${ }^{1}$ - Carolina Alves Pereira Corrêa ${ }^{3}$ - Angel Mauricio Castro-Gamero ${ }^{3}$. \\ Elton José Rosas de Vasconcelos ${ }^{4} \cdot$ Ricardo Santos de Oliveira $^{5} \cdot$ Luciano Neder $^{6}$. \\ José Andres Yunes ${ }^{7} \cdot$ Simone dos Santos Aguiar ${ }^{7} \cdot$ Carlos Alberto Scrideli $^{3}$. \\ Luiz Gonzaga Tone ${ }^{1,3}$
}

Published online: 29 November 2016

(C) Springer Science+Business Media New York 2016

\section{Erratum to: Invest New Drugs \\ DOI 10.1007/s10637-016-0401-4}

Due to a formatting error, the name of one of the authors, Simone dos Santos Aguiar, appeared as Simone Santos dos Aguiar. The correct authors' name is as shown above. The original article was corrected.

The online version of the original article can be found at http://dx.doi. org/10.1007/s10637-016-0401-4.

Augusto Faria Andrade

augustofaria@usp.br

1 Department of Genetics, Ribeirão Preto Medical School, University of São Paulo (USP), Avenida Bandeirantes 3900,

14048-900 Ribeirão Preto, SP, Brazil

2 Departamento de Genética, Faculdade de Medicina de Ribeirão Preto, Universidade de São Paulo, Avenida Bandeirantes 3900, 14048-900 Ribeirão Preto, SP, Brazil

3 Department of Pediatrics - Ribeirão Preto Medical School, University of São Paulo (USP), São Paulo, Brazil

4 Department of Biochemistry, Chemistry Institute, USP, São Paulo, Brazil

5 Department of Surgery and Anatomy, Ribeirão Preto Medical School, USP, São Paulo, Brazil

6 Department of Pathology, Ribeirão Preto Medical School, USP, São Paulo, Brazil

7 Centro Infantil Boldrini \& FCM/Unicamp, Campinas, Brazil 